\title{
The Multiple Use of Tropical Forests by Indigenous Peoples in Mexico: a Case of Adaptive Management
}

\author{
Víctor M. Toledo ${ }^{1}$, Benjamín Ortiz-Espejel, Leni Cortés, Patricia Moguel, and María de Jesús Ordoñez
}

\begin{abstract}
The quest for an appropriate system of management for tropical ecosystems necessitates that ecologists consider the accumulated experiences of indigenous peoples in their long-term management of local resources, a subject of current ethnoecology. This paper provides data and empirical evidence of an indigenous multiple-use strategy (MUS) of tropical forest management existing in Mexico, that can be considered a case of adaptive management. This conclusion is based on the observation that some indigenous communities avoid common modernization routes toward specialized, unsustainable, and ecologically disruptive systems of production, and yet probably achieve the most successful tropical forest utilization design, in terms of biodiversity conservation, resilience, and sustainability. This analysis relies on an exhaustive review of the literature and the authors' field research. Apparently, this MUS represents an endogenous reaction of indigenous communities to the intensification of natural resource use, responding to technological, demographic, cultural, and economic changes in the contemporary world. This transforms traditional shifting cultivators into multiple-use strategists. Based on a case study, three main features (biodiversity, resilience, and permanence) considered relevant to achieving adaptive and sustainable management of tropical ecosystems are discussed.
\end{abstract}

\section{INTRODUCTION}

Indigenous strategies of use and management of the tropical lowland ecosystems have, for decades, been exclusively identified with shifting (swidden, slash and burn, or nomadic) cultivation practices. Shifting cultivation has recurrently been described as a low productivity system, wasteful of natural resources (FAO 1957) and, consequently, shifting cultivators have been considered destroyers of tropical forests or, simply, remnants of ancient educated societies (Cook 1921, Watters 1971). With this in mind, scientists, probably since the mid- $19^{\text {th }}$ century, have focused their attention exclusively on cultivation systems, overlooking the management of ecological processes and the relevance of non-agricultural activities such as agro-forestry, hunting, gathering, fishing, and, more recently, cattle ranching, forestry extraction, plantations, and cash crops (see Alcorn 1989b, Warner 1991, Toledo et al. 1994). Apparently, this biased view was a mechanistic application of the stereotype derived from the industrialized farmer in temperate zones to the peasant's practices in the humid tropics. In other words, scientists overlooked indigenous practices and management of ecological processes because they were fixated on an agronomic-centered approach.
This misconception, which has long pervaded the minds of many scholars, is now being challenged (Pierce-Colfer and Dudley 1993) and many researchers now believe that shifting cultivation is a more benign alternative, in terms of environmental effects, than most other permanent farming systems in the humid tropics (Thrupp et al. 1997, Mertz and Magid 2003). Moreover, a growing number of research projects carried out over the last two decades, have demonstrated that contemporary indigenous cultures manage tropical humid ecosystems by practicing a strategy that involves many land uses and a myriad of resources (e.g., Alcorn 1990, Denevan et al. 1984, Dufour 1990, Marten 1986, Posey and Balée 1989 , and others). This represents a reinterpretation of the shifting-cultivation idea in light of new evidence and approaches (Warner 1991). Such a new paradigm agrees with available archeological and ethnohistorical evidence from ancient cultural areas, such as those of the Maya (Harrison and Turner 1978) or those of Amazonia (Roosevelt 1989), that indicates ancient manipulation of the tropical forests. As a whole, these contributions demonstrate that indigenous peoples practice an intensive management of tropical forests and of other ecosystems, including not only manipulation of species and other natural items, but 
also of the underlying ecological processes (Alcorn 1989b). In summary, they practice what has been called adaptive management based on multiple use of species, resource rotation, landscape-patch management, and succession management (Berkes et al. 2000).

Following the above line of thought, this paper describes a management strategy adopted by some indigenous groups inhabiting the tropical rain forest areas of Mexico that seems to be an endogenous response to the new demographic, cultural, technological, informational, and economic conditions of the contemporary world. These conditions include new links with regional, national, and even global markets, adoption of new technologies, higher population densities, access to new sources of information (oral, written and electronic), innovative forms of local, social, and political organization, and new means for transportation and communication. Although previous reports on indigenous use of tropical humid resources in Mexico have outlined some aspects of this strategy (Gomez-Pompa and Kaus 1990, Cortés and Toledo 1991, Alcorn and Toledo 1998), in this paper, we synthesize widely scattered data and provide a detailed review of this indigenous utilization of nature. By means of a case study, we emphasize the conservationist, ecological, and economic implications of this indigenous strategy, as well as its practical importance.

\section{INDIGENOUS PEOPLES AND TROPICAL RAIN FORESTS IN MEXICO}

According to a survey carried out by the authors, the tropical humid area originally covered by rain forests in Mexico was distributed across about 324 municipalities throughout nine states, covering an area of 20.6 million ha (10\% of the total Mexican territory). Although Mexican tropical areas are ecologically similar to other hot and humid areas of the world, they have a unique set of social, economic, demographic, and cultural features (Gomez-Pompa et al. 1993) that derive both from long human presence in the area and from the processes of recent rural modernization.

Based on the 1990 National Population Census, we identified 22 indigenous groups inhabiting the tropical moist zones of Mexico, with a total population of 1.56 million. This figure represents $18 \%$ of the total population of this ecological zone (Table 1) and nearly half the rural productive units (ejidos and Indian communities). Contrary to common perception, during the decade of 1980-1990 the indigenous population inhabiting the tropical humid areas of Mexico grew from 1.39 to 1.56 million (Table 1), which indicates a certain amount of success in their production systems. This latter figure exceeds the number of indigenous peoples living in the entire Amazon Basin, which has been estimated at over one million (Davis and Wali 1994).

The indigenous cultures living in these areas (Fig. 1) can be divided into four well defined groups: a) groups whose main habitat is within this ecological zone (Chinantecs, Chontals of Tabasco, Totonacs, Huastecs, Zoques, and Lacandons), b) groups in which the bulk of the population lives in other ecological zones and only part of which lives in the tropical moist habitat (Zapotec, Maya, and Nahua), c) groups represented in this ecological zone only by a scarce population (Otomi, Tepehua, Huave, Mixtec, Mame, Chatino, Mixe, Popoluca), and, d) groups that are new to the area, who have recently colonized it as a result of migratory movements (Tojolabal, Tzeltal, and Tzotzil).

Despite the fact that the Mexican humid tropics have been inhabited by indigenous groups over long periods of time, dating back 600 (Totonacs) to 3000 years (Huastecs), to this date, they are not isolated societies. In fact, indigenous groups in Mexico-paralleling other indigenous and non-indigenous tropical peasants, such as the farmers of several South Asian nations, the ribereños of Peru, or the caboclos of Brazil-are peasant producers who are, in general, well integrated into society at the national, and even the international, level through economic exchange, roads, technological alternatives, communication media, and national educational and cultural programs. Although this longterm process of integration originated at the time of the Spanish colonization, it has been especially accelerated in the last four decades, during which time the Mexican humid tropics have been completely integrated to the national level.

There are still some large portions of the humid tropics, such as the Amazon Basin, some Indonesian islands, or the Atlantic side of Central America, that have yet to be integrated into national and global societies, however, the tropical rain forest areas in Mexico have had railroads since the end of the $19^{\text {th }}$ century and graded roads since 1925 (Revel-Mouroz 1972). After an intensive period of road construction (between 1956 and 1970), the Mexican humid tropics were finally integrated into the nation by both land and 
air toward the end of the 1970s. Consequently, most indigenous peoples inhabiting the humid tropics are peasants or small-scale farmers with potential access to most of the basic services, technologies, and information available to the rest of Mexico. Therefore, although this paper focuses on the study of Mexican indigenous groups, its results can be extrapolated to other regions of the humid tropics around the world that have similarly been transformed by the powerful and relentless processes of national and global integration.

Fig. 1. Geographical distribution of the indigenous groups inhabiting the humid tropics of Mexico. Source: based on Table 1.

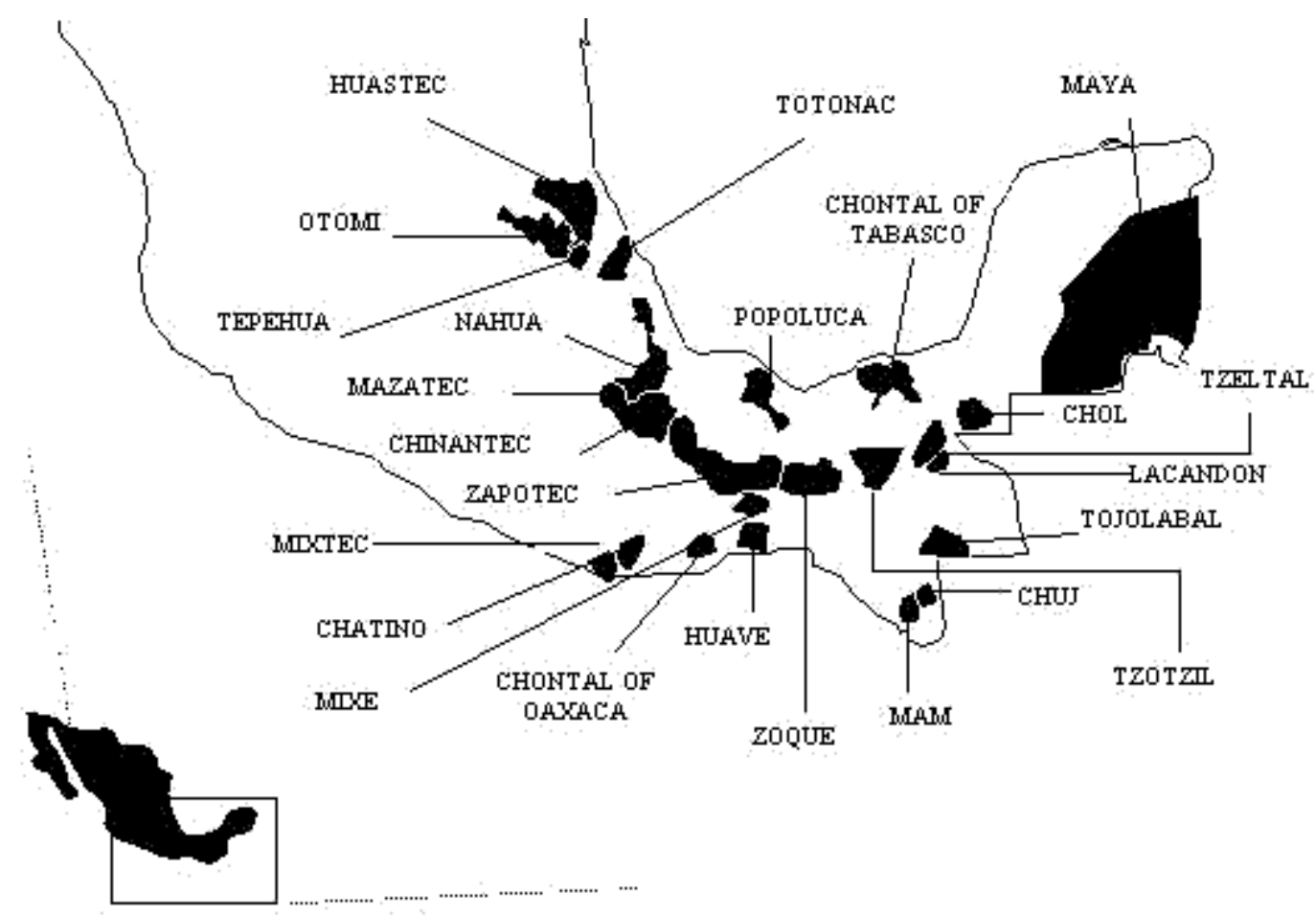

\section{INDIGENOUS MANAGEMENT OF TROPICAL RAIN FORESTS IN MEXICO: UNDERSTANDING A STRATEGY}

Recognition of indigenous management strategies in the world's tropical humid areas has recently gained credit. The term "resource management strategy"and other related terms, such as "subsistence pattern" (Dufour 1990) or "agro-forestry system" (Alcorn 1990) — has been deliberately used in the literature to denote an indigenous mode of proper appropriation of tropical ecosystems (Posey and Balée 1989). However, in theoretical terms, this recognition has not received sufficient attention, with the exception of a remarkable paper by Alcorn (1989b), in which she uses the statement: "an internalized plan used by people carrying out and interpreting routine activities," to denote a similar intellectual construction.

In a strict sense, the concept of strategy means the construction of a plan or scheme of linked operations in order to achieve an explicit goal: it is the art of designing and directing operations. Thus, by using the label "strategy," we wish to stress an intellectual construction or internalized plan among indigenous producers who, to the Western-educated eye, generally appear as illiterate peoples without the capacity to manipulate and create mental pictures of nature.

The explicit recognition of an indigenous strategy has, in addition, an intrinsic heuristic value. It can be contrasted with other (non-indigenous) strategies, and it can serve as an example to be emulated, enriched, evolved, or transformed. In the last instance, the 
recognition of a resource management model or strategy is a crucial methodological step in any ethnoecological research approach (for a theoretical discussion of this topic see Toledo 1992, 2002). Moreover, from an historical perspective, the search for and recognition of an indigenous strategy is closely linked with the more general concept of an ecological rationale of peasant appropriation of nature (Toledo1990, 1995), that has predominated, and continues to do so, over enormous areas of the Third World.

Similarly to all peasant farmers around the world, the indigenous peoples of the tropical humid areas of contemporary Mexico are immersed in a dual economy. They produce goods for the market and buy goods using cash yet, at the same time, they produce basic commodities for their own consumption. As a result, they are obliged to adopt a strategy that encompasses their dual role as subsistence and market producers. Therefore, the main objective of the indigenous strategy is to maximize the diversity and the number of available options, in order to guarantee its subsistence and to minimize the risks. This is achieved through the multiple use of space, time, and the plant, animal, and fungi populations and communities.

A review of available current ethno-ecologically oriented literature involving research on these groups, together with the authors' own observations and field work among the Totonacs, Chinantecs, Chatinos, Tzeltales, and Chontals of Tabasco, allows us to distinguish a complex system of management, which - in its optimum version-tends to include six main productive units. A heterogeneous landscape has been created in the humid tropics of Mexico, formed by a mosaic of patches of primary and/or secondary (managed and unmanaged) forests, swidden fallow tracts, vegetation corridors, water bodies, home gardens, and more permanent fields dedicated to cultivated plants, cattle, and forestry plantations (Fig. 2).

\section{A DIVERSIFIED SYSTEM OF MANAGEMENT}

Milpa - the corn field-is the pivotal element of this diversified system of management (Alcorn and Toledo 1998). This central role derives from its importance as a product (maize provides $65 \%$ of the protein and $71 \%$ of the calories of Mexican peasants; see DeWalt (1983)), as well as from cultural (the Mesoamerican civilization was established on the basis of maize cultivation, a fact recurrently expressed in its mythologies, beliefs, and festivals) and social reasons (maize defines land tenure, reciprocity relations, and other social interactions; for more details, see Alcorn and Toledo (1998)). Like other indigenous cultures of the Neotropics, the indigenous peoples in Mexico have a tendency to establish poly-agricultural fields. These poly-specific and poly-genetic parcels are formed by domesticated, semi-domesticated, protected, and tolerated species. Thus, a remarkably high number of plant species are commonly represented in corn fields (Table 2 and see the Discussion). In addition to the milpa, plantations - which are here considered to be areas of monoculture whose production is directed mainly to the markets (cash crops) - are also cultivated. Depending on market demand and environmental conditions, plantation fields have been planted either with tobacco, sugar cane, coconut palms, bananas, citrus, pineapples, sesame seeds, chili peppers, or rubber. On the landscape, these fields appear as a pattern of patches of monoculture intermingled with diversified traditional crops.

Potreros comprise the third element of the diversified system; these are relatively small grazing areas for cattle. Despite the fact that these areas are basically pasturelands, they are not exclusively composed of grasses. In many cases, pastures include legume trees and shrubs, that are grazed on by cattle. Commonly, these livestock-raising areas have a dual purpose to produce both meat and milk, and animals are rotated frequently (Ortíz-Espejel 1999). Managed and unmanaged forests are also included in the management system.

Comparable to other tropical cultures, the indigenous groups of Mexico recognize, use, and manage the different successional stages of secondary forests. According to Brown and Lugo (1990), secondary forests have resulted from the abandonment of cleared forest lands for productive practices, such as for shifting cultivation (with long or short cultivation periods), small or large forestry clearings, pastures, or plantations. Although their age varies, we consider secondary forests to be those less than 60-80 years old because, beyond this age, these plant communities are often indistinguishable from primary forests (Brown and Lugo 1990). This coincides with the absence in the indigenous languages of labels for the masses of vegetation older than this age. On the other hand, mature forests are used as the main source of several products of plant and animal origin, which are obtained through gathering, extraction, and hunting. 
Fig. 2. Generalized scheme of the production system created and used by indigenous households and communities of tropical humid lowlands of Mexico, and its landscape (or land-use) units. The system includes the use and management of mature forests (A), secondary forests and their stages (A1 to A4), managed forests resulting from the manipulation and introduction of species in the mature forests (A-I to A-IV), milpa or corn fields (B), potreros or cattle-raising areas (C), cash-crops or agricultural fields other than milpa (D), water bodies (E), and home gardens (F). The production system is represented in an idealized version. Depending on its environmental, social, and economic conditions, each household utilizes several or all of the landscape units as part of its multiple-use strategy (MUS) of management.

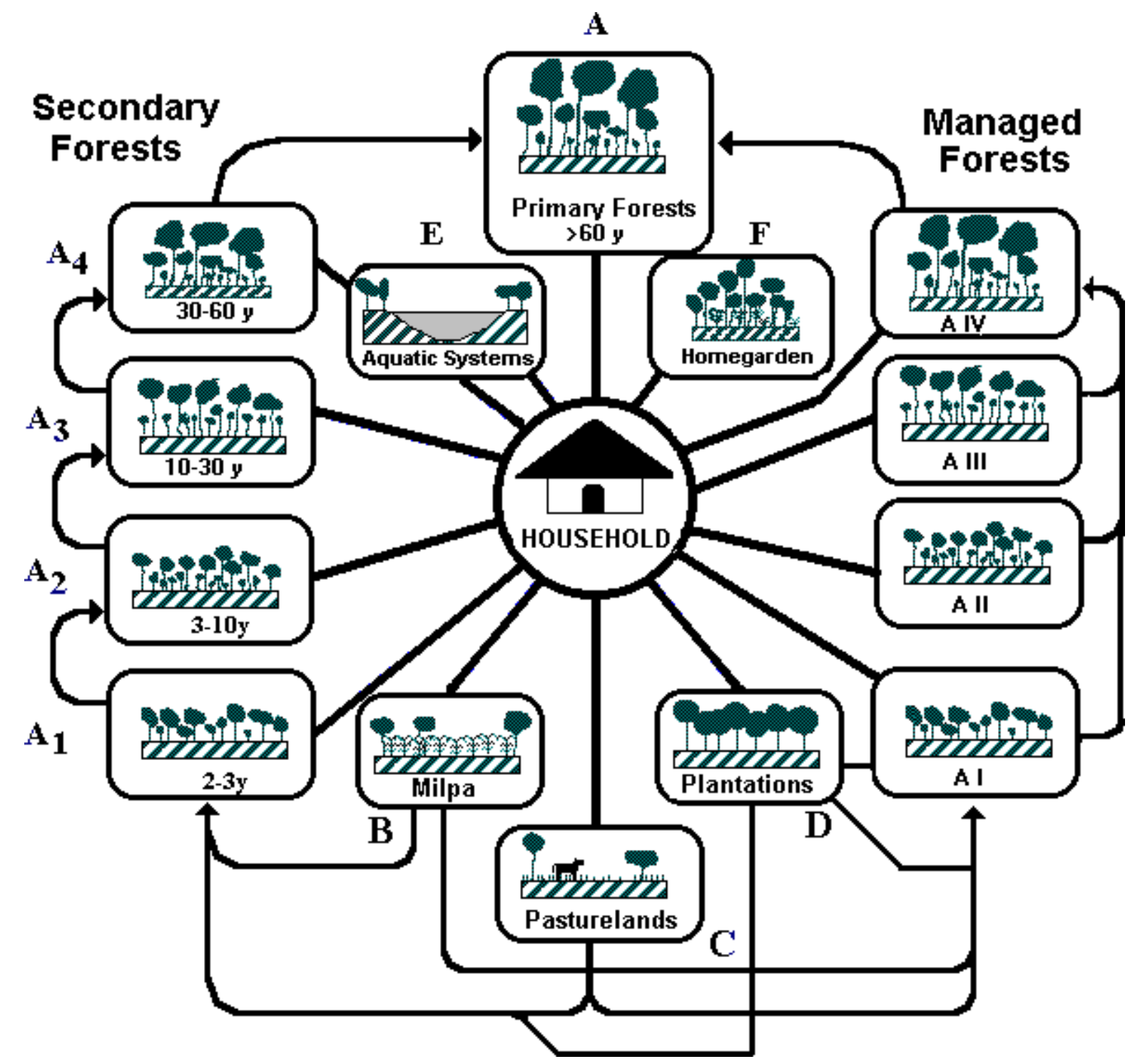

Managed or "artificial" forests are masses of vegetation where useful non-native species are introduced and manipulated. As in the rest of the Neotropics (see Alcorn 1990), managed forests in Mexico range from primary or mature forests that have been enriched with some non-native species (such as poly-specific orchards with a few native species) to plantations where a single species of tree crop (e.g., coffee or cacao) is mixed with a few native tree species. Thus, we can trace a spectrum of managed forests going from those that are almost entirely dominated by native tree species to those nearly dominated by non-native tree species.

Finally, these productive units are complemented by home gardens and, where availability of water bodies 
makes it possible, by utilization of the aquatic resources of streams, rivers, and lagoons. As in other areas of the humid tropics of Latin America (Alcorn 1990), the solar or home garden is an agro-forestry system that is usually located next to the house, and is supplementary to the activities mentioned above, being fundamentally managed by the women of the household. With the exception of the Lacandones (who inhabit the southern border of Mexican territory), home gardens are found in all the reviewed studies about indigenous management of natural resources. In summary, the MUS is manifested in the creation of a diversified productive system where agriculture, cattle raising, and forestry activities are sustained in an equitable way through the maintenance of a set of productive units. This landscape diversity presents, in turn, a dynamic functioning expressed in cycles of forestry-agriculture-forestry, etc., that is the result of the permanent tension existing between the regenerative forces of nature (forest regeneration) and the human forces that transform the forest ecosystems (see the Discussion). As a result, indigenous farmers successfully obtain products both for consumption and for the market, thereby achieving an economy in which self-sufficiency is complemented by surplus.

Different versions of this diversified system have been explicitly or implicitly recognized and reported by researchers in case studies of such ethnic groups as the Huastecs (Alcorn 1981, 1983, 1984), Totonacs (Kelly and Palerm 1952, Medellín 1988), the Chinantecs (Lucero and Avila 1974, Martin 1993; F. Bandeira personal communication), the Mazatecs (Cabrera et al. 2001), the Chontales of Tabasco (Vázquez-Dávila 2001), the Zoques (De Ita 1993, 1994), the Nahuas (Arellano 1985), and the Lacandones (Nations and Nigh 1980, Nigh and Nations 1983), all of which seem to present local and regional variations of the same pattern. Even the Tzeltal indigenous communities, which have very recently colonized the lowlands of the Selva Lacandona in Chiapas, possess a subsistence strategy that is based on the multiple use of natural resources (Toledo and Carrillo 1992). The recognition of local terms for the landscape units of the entire system (Fig. 3) confirms the existence of this management strategy among various indigenous groups.

\section{ECOLOGICAL ECONOMICS OF THE INDIGENOUS STRATEGY: A CASE STUDY}

The MUS can be empirically described in detail through an ecological-economic analysis of the village
Plan de Hidalgo, an indigenous community located in the tropical humid lowlands of the Totonacapan region in Veracruz (for further details see Toledo et al. (1994)). Plan de Hidalgo is a typical indigenous community where $80 \%$ of the people speak the Totonac language. According to the 1990 population census, the community had 877 inhabitants distributed in 166 households. Most households (72\%) possess between 7 and 9 ha of land, which reflects the equity of access to communal resources. In contrast, only $9 \%$ of the households manage more than 9 ha and $19 \%$ have less than 7 ha. The total area of territory held by the community is 1519 ha. Medium-sized tropical humid forests comprise the main type of vegetation in the community.

Like many other peasant farmers in Mexico, the Totonac Indians of Plan de Hidalgo are immersed in a dual economy: they produce goods for the market and buy goods with cash, but at the same time they produce basic goods for their own consumption. An ecological-economic analysis of the strategy adopted by each of the 166 households in the indigenous community was made by the authors between 1990 and 1993. The survey revealed the existence of six main production or land-use units, each having a landscape or spatial representation. (1) The milpa or maize field is usually a rain-fed multi-species system, in which maize is combined with almost any other local crop or tree or shrub species. Over 70 tolerated or cultivated plant species have been identified in the corn fields of the village. Maize is harvested twice a year. It is common for a milpa to be cultivated for 2 or 3 years, with successive fallow periods of 3 (short fallow) to 12 (long fallow) years. (2) Cash-crop fields. In addition to the multi-species milpas, Totonac Indians also manage small areas with monocultures of sugar cane, oranges, sesame seeds, beans, and chilies. These monocultures are generally planted as cash crops. (3) Home gardens or solares. In Plan de Hidalgo, the home gardens have a three-layer stratification of tree canopies combined with an herb understorey. Over 100 plant species have been identified in the home gardens of the studied village, primarily for medicinal, food, fuel, construction, and ornamental uses. In addition, solares also house domestic animals such as swine, chickens, turkeys, pigeons, and wild pheasants (chachalacas). A few households also keep native bees on a small scale in their home gardens. (4) Potreros (cattle-raising areas). Cattle is raised in the community in a small-scale, multi-species system. This practice is exceptional in a region where extensive cattle grazing is the prevalent 
(and even sole) system employed by most of the indigenous and non-indigenous settlements. As mentioned above, the livestock areas of the community are grass-dominated pasturelands combined with scattered legume trees and shrubs (Ortiz-Espejel 1999). (5) Vanilla groves and (6) Secondary and mature forests. The Totonacs collect and extract products from managed and unmanaged forests. Such forestry products, including vanilla (a climbing orchid that produces an aromatic fragrance), wild fruits, palm leaves, and firewood, are the main forestry products. Vanilla is sold as a much desired cash crop, but fuelwood is the main energy source of the community. In addition, the Totonacs use over 200 other species of plants, animals, and fungi from the mature and secondary forests (Table 4).

Fig. 3. Representation of the land-use units (names below) and the local names (above) given to them by four indigenous groups of the tropical humid areas of Mexico. Sources: Huastecs (Alcorn 1983, 1984); Totonacs (Medellín 1988, OrtizEspejel 1995); Mazatecs (Cabrera et al. 2001); Chontals (Vázquez-Dávila 2001).

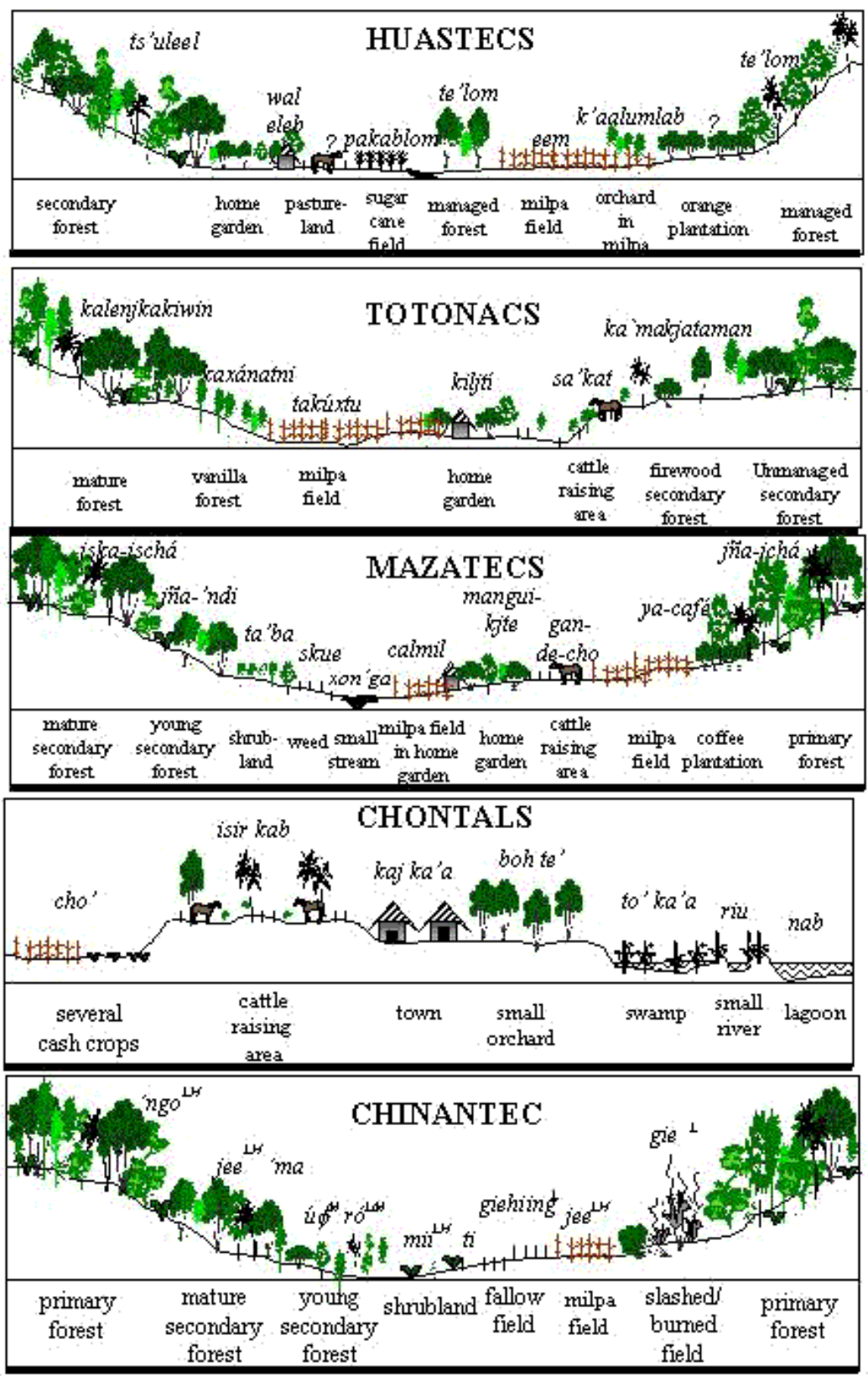


Fig. 4. Land-use patterns adopted by households of the indigenous community of Plan de Hidalgo, Veracruz. A to F indicate the six combinations of land uses recognized in the village. Numbers indicate the average surface per landscape unit in hectares, with the exception of home gardens of less than 0.25 hectares. The percentage of households adopting each land-use pattern is also indicated. The letter X indicates the presence of home gardens. All calculations are based on the total number of households.
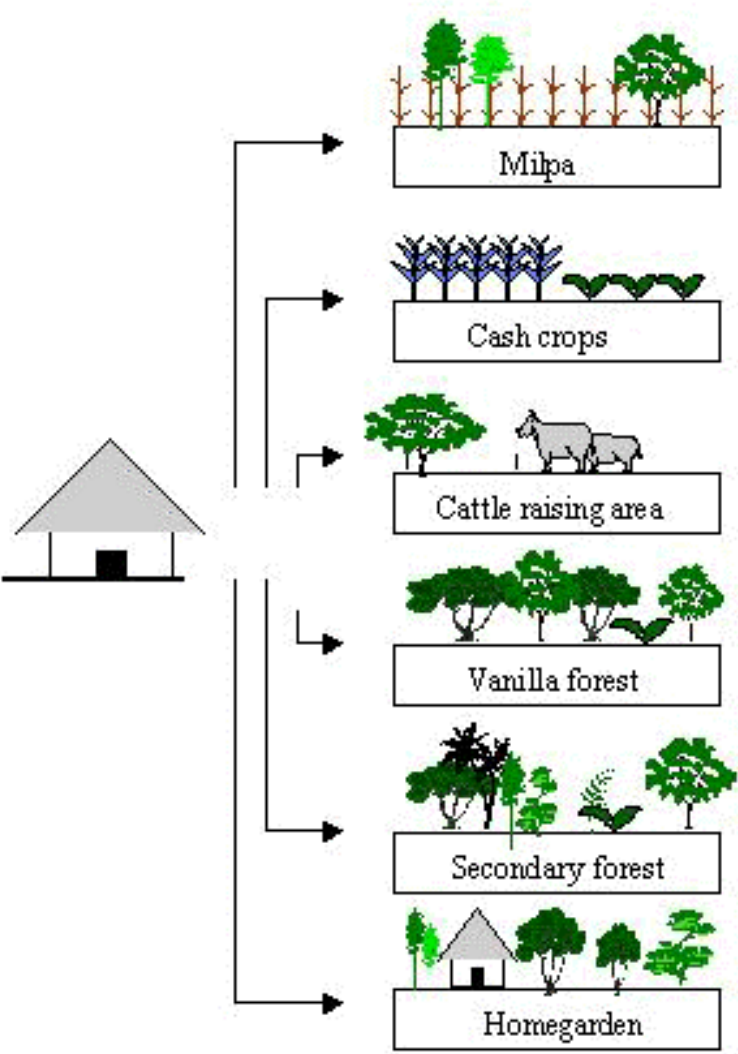

Households (\%)

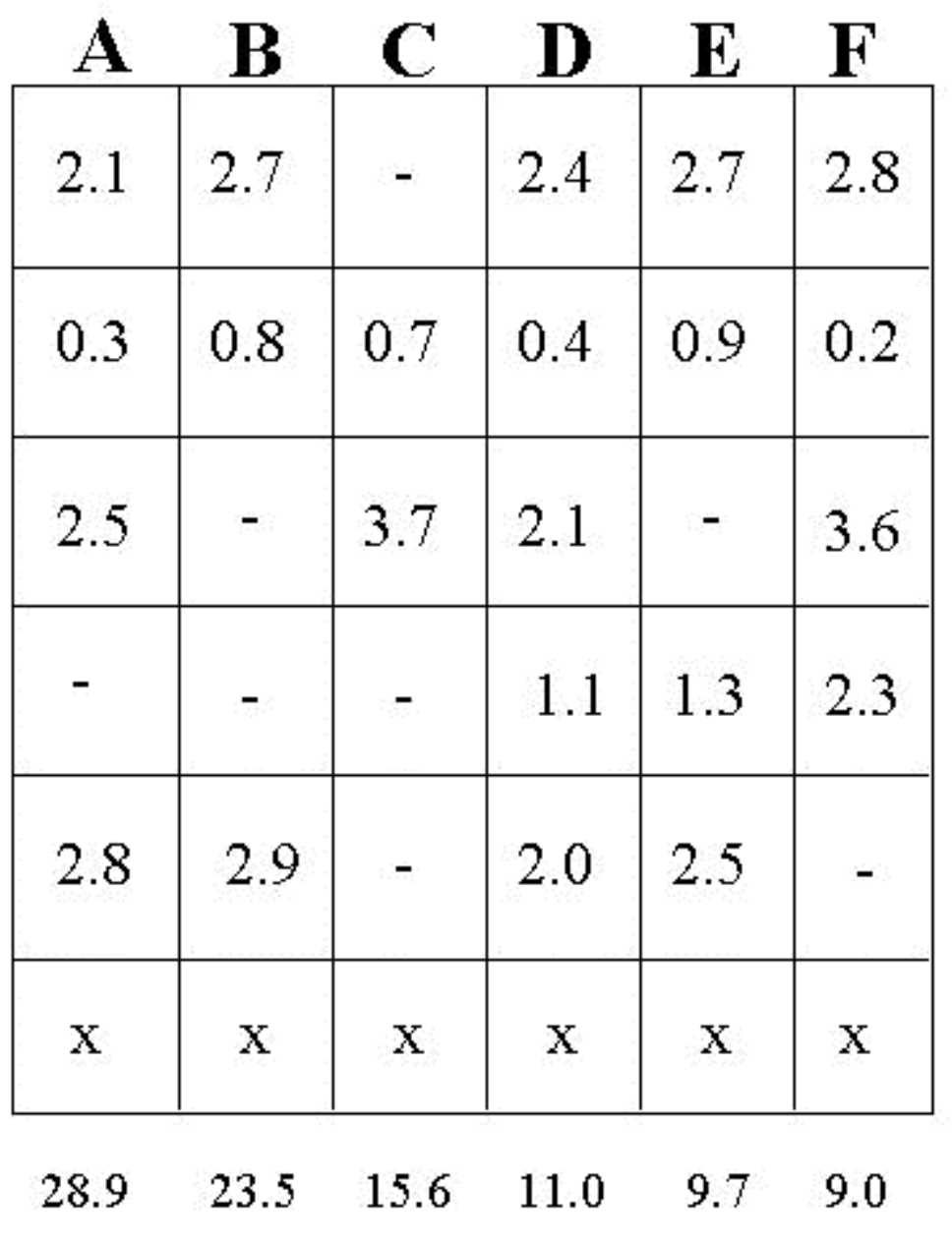

Most households utilize three or more production or land-use units. Therefore, the landscape surrounding the village is a spatial representation of the generalized adoption among the households of a strategy that combines agricultural, cattle-raising, and forestry practices. Each household utilizes these landscape units in a different combination (Fig. 4). Practically all households include milpas and home gardens as part of their production strategies. Three quarters of them maintain and use patches of forests and two thirds, employ potreros. The two main landscape units dedicated to cash-crop production are: the commercial agricultural lands where the Totonacs grow sugar cane, oranges, and other crops, which are utilized by $47 \%$ of the households; and the vanilla forests, used by $30 \%$ of the households. In general, the main strategies adopted by the majority of the households are profitable in economic terms. Thus, the balance between cash and non-cash (shadow price) inputs and the total benefits (which include products consumed by household members) is always positive. Our calculations indicate that, in a typical household having 8 ha of land, a total of over 400 workdays per year, plus a minimum amount of monetary input, allow for both food and energy self-sufficiency, plus an economic return of more than U. S. \$1000/ha/year (Toledo et al. unpublished data). A similar situation of cost-benefit balance was reported by Alcorn (1989a) among the Huastecs: a typical land holding in a Huastec community yields a net benefit of cash and subsistence goods valued at U. S. \$98/ha/year. These figures contrast favorably with the low prices for most 
cash crops in the regional markets and with the official minimum wages of Mexico (about U. S. $\$ 1440$ per year in 2002).

With respect to the ecological-economic role of indigenous households, mature and secondary forests, home gardens, and part of the milpa provide the main products for local consumption (principally foods and fuel). The potreros, vanilla forests, and/or cash-crop areas, and part of the milpas and mature forests provide products for the market. Under this dual rationale, the indigenous producer switches from being a shifting cultivator to a multiple-use strategist, a move that makes sense in terms of the game theory. In fact, as decision-makers, they determine how much labor to put into each of the various land-use (or ecogeographical) units so as to obtain the best "pay-off" under various environmental and economic scenarios.

Fig. 5. Land-use microhistory (1950-1995) of parcels belonging to three farmers in the indigenous community of Plan de Hidalgo, Veracruz, showing different routes toward the conversion to pasturelands for cattle. Contrasting with case A, where a sequence of different land uses dominated over the time period recorded, cases B and C finish by restricting the multipleuse management strategy. Source: Authors’ field work.

time

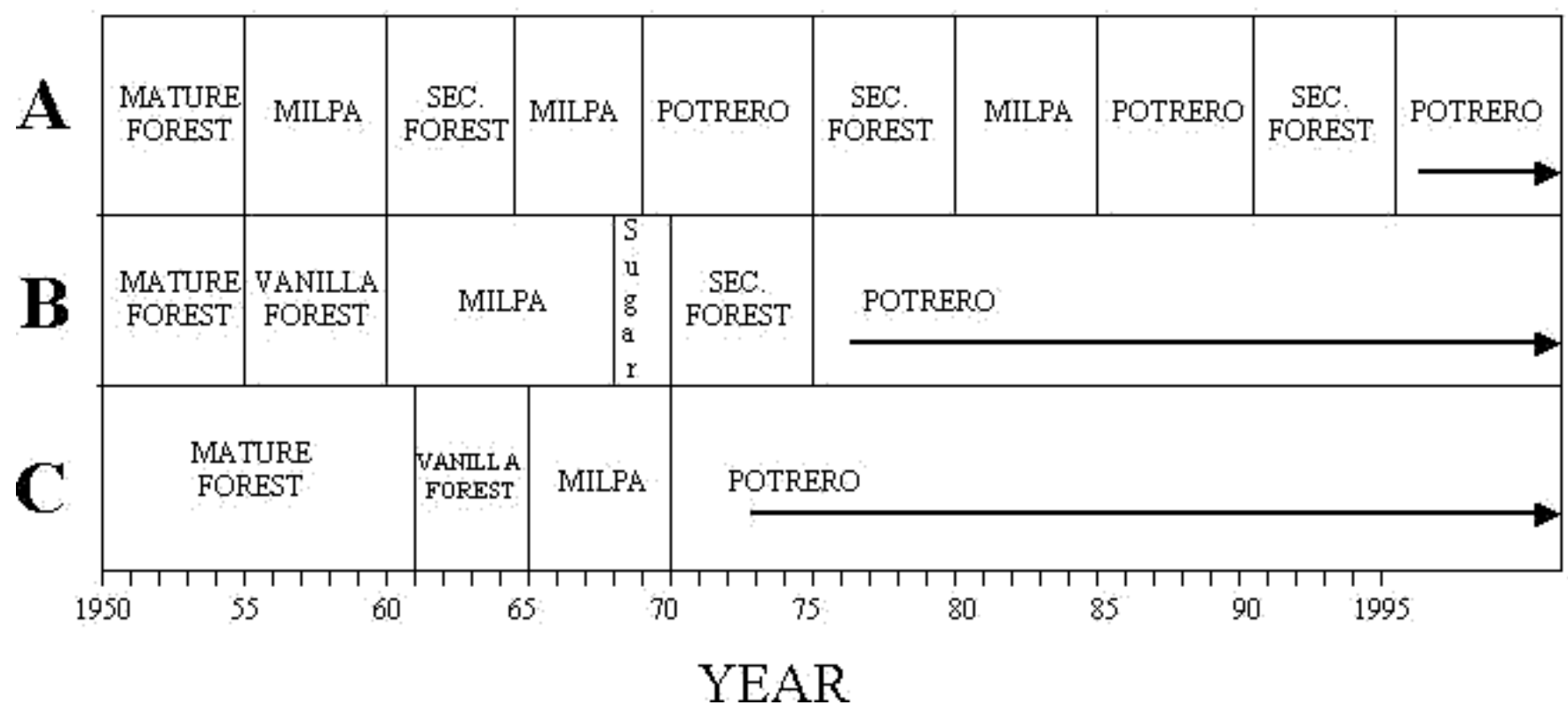

Despite this economic productivity, the households continually face different internal constraints and bottlenecks, as well as external threats, which undermine the permanence and reproduction of the entire system. For example, when the market success of a productive unit induces disruption of the normal cycle of agriculture and forestry, thus restricting the productive amplitude only to one activity, the MUS begins to be dismantled (see Fig. 5). Thus, households must avoid product specialization and maintain not only a certain degree of spatial heterogeneity or patchiness, but also a dynamic based on a sequence of productive units, which in turn are based on the natural restoration of forests.

\section{DISCUSSION}

In general terms, rural development in the humid tropics has been a catastrophic process accompanied by worldwide deforestation (and the drying up of wetlands), reduction of biodiversity, and specialization and dislocation of native productive strategies for the management of tropical forests. The obvious consequence of the above situation is the bioecological, economic, and socio-cultural impoverishment of the land, the biota, and the people. The current eco-social crisis has demonstrated that, with very few exceptions, conventional modernization is fundamentally limited in its ability to promote 
equitable and sustainable development. In Mexico, as in the rest of the world's tropical lowlands, modernization has had a catastrophic and unhappy effect (Tudela 1989), which has prompted high deforestation rates and a significant reduction in mature tropical forests to nearly $10 \%$ of their original geographic distribution (Masera et al. 1997). This is the result of both governmental projects (particularly during the last four decades), many of which were supported by international banks, and the absence of an appropriate planning policy.

In contrast, it seems clear that the indigenous natural resource use described in this paper has obvious advantages over conventional "modern" productive models, which in every part of the tropical world propagate a simplified model for the appropriation of nature. On the whole, indigenous communities following the described strategy have developed a relatively stable and satisfactory land-use system that possesses three remarkable characteristics essential for sustainability (see Noble and Dirzo 1997): a) it maintains high levels of biodiversity, b) it is highly resilient, and c) it tends to be maintained for long periods of time. We briefly discuss each in turn.

\section{Maintenance of biodiversity}

The current trend appears to be a simplification of the world's biota as a result of human activities. However, researchers are coming to the realization that the creation of landscape mosaics under indigenous management in areas that were originally covered by only one kind of ecosystem, represents a humanoriginated mechanism which, theoretically, tends to maintain and even increase biodiversity. At the same time, the idea that maintaining a productive landscape with a variety of uses and ecosystems is the best strategy to maintain biodiversity has gained consensus among scholars (Pimentel et al. 1992).

Maintenance of biodiversity under an MUS can be confirmed by the elevated number of useful species that are utilized by indigenous cultivators at different levels. This "useful biodiversity" can then be evaluated across the different land-use units, including parcels, masses of vegetation, and the entire system. In general, each landscape unit under this indigenous management tends to be a multi-species system. For instance, the species composition of milpas and home gardens alone reveals a high number of useful plant species in these poly-cultural designs: in eight milpa parcels for which data were available, the number of plant species (including trees, shrubs, herbs, and vines) reached an average figure of 30 (Table 2). On the other hand, the accumulated number of useful plants in milpas and home gardens at the community level is between 65 and 124 species, and between 60 and 250 species, respectively (Table 3). Similarly, some managed forests, for example, the multi-species shade coffee agro-forests, are important repositories of biological richness for groups such as trees, epiphytes, mammals, birds, and arthropods (Moguel and Toledo 1999).

This richness, plus the useful species that are obtained from unmanaged secondary and mature forests, gives rise to a myriad of utilitarian items. For example, in the Totonac village analyzed in this paper, the total number of useful plant, animal, and mushroom species throughout the various landscape units alone is 355 (Table 4). The Huastecs use 679 plant species and specifically "manage" 349 of these species (Alcorn 1984). When analyzed on a global basis, this "useful biodiversity" becomes impressive. A quantitative survey of the useful flora based on the ethno-botanical studies carried out among ten indigenous groups inhabiting the humid tropics of Mexico revealed a total of 1330 useful plant species and 3173 "products" (Toledo et al. 1995). These figures are the final expression of the multiple-use management of the plant universe: 297 species come from the mature forests, 595 from the secondary forests in their different successional stages, 160 from both of these, and 278 from milpas and home gardens (Fig. 6). Analysis of this variety by use reveals a broad spectrum: medicine, food, lumber and construction materials, forage, fuel, domestic items, ornamental, work instruments, etc. (Fig. 6).

\section{Resilience}

It seems that the multiple use of tropical forests by indigenous peoples of contemporary Mexico represents a case of social-ecological resilience (Alcorn and Toledo 1998). Resilience can be defined as the capability of a system to recover its level of productivity potential following a perturbation. According to Holling (1973), resilience can be measured by the magnitude of disturbance that can be absorbed before the system redefines its structure by changing the variables and processes that control its behavior. Where local communities and their institutions become an active part of the dynamics of its local ecosystems, they possess high levels of resilience. This is the result of the flexibility of the 
local institutions combined with a strong cultural support, which allows the system to resist, isolate, adapt, enhance or neutralize external disturbances. In the case examined, the internal and external forces threatening local social-ecological systems are represented by new economic demands and opportunities, new technologies, new sources of information and communication, changes in human population density, intensity of resource extraction or a combination thereof.

Fig. 6. Number of plant species per landscape unit utilized by ten indigenous groups of the tropical lowlands of Mexico (Huastecs, Totonacs, Otomis, Chinantecs, Nahuas, Popolucs, Zoques, Mayas, Lacandons, and Chujs) as reported by ethnobotanical research. Boldface numbers indicate the total number of species per landscape unit. Note that only one figure is given for milpa and home gardens. Source: Authors' ethnofloristic data bank; for further details see Toledo et al. (1995).

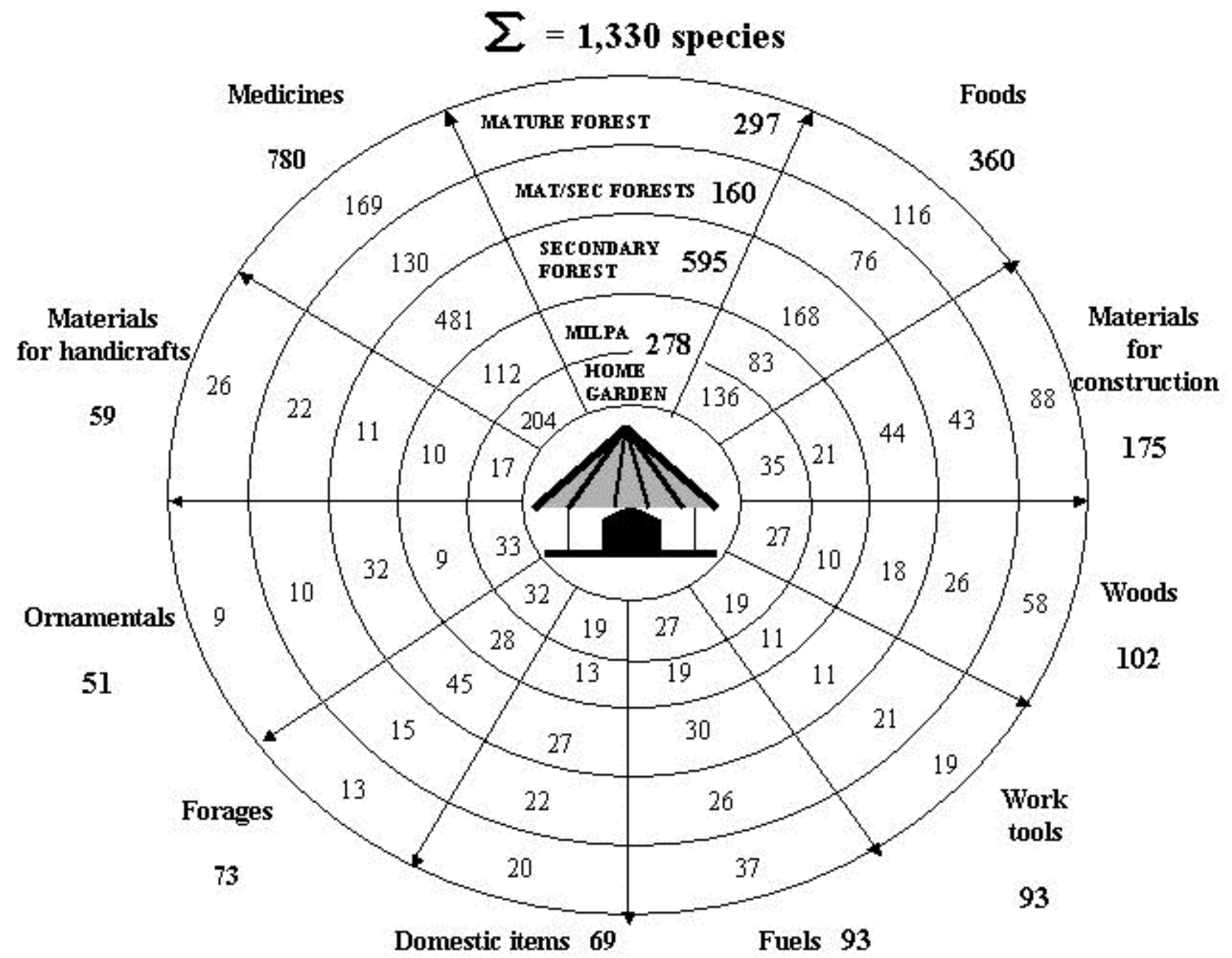

It can be assumed that, for centuries, shifting cultivation was the primary mode of use of tropical forests among the indigenous peoples inhabiting the humid tropics of Mexico. However, this traditional pattern has gradually or abruptly been modified due to the integration of the indigenous communities into the regional, national, and global markets, under which their population numbers have increased and they have adopted new cultivars, domestic animals, and technologies. Particularly important for this transition was the role played by the new cultivars, domesticated animals, and wild species that have some market value (cash crops, livestock, and commercial natural products), because these products increased the 
economic return and brought about the modification of the original management strategy of the tropical lowland ecosystems. In general terms, indigenous households and communities may be integrated into the markets in two ways: (1) by re-creating, adapting, and enhancing the diversified (multiple-use) strategy of shifting cultivation, which is an inherent property of the indigenous rationale; or (2) by transforming (and displacing) the above strategy with a specialized practice where all that is produced is solely marketoriented (for a theoretical discussion of this dilemma see Toledo (1990)). Again, the case examined in the previous section illustrates, at a micro-social level of detail, the changes that occurred when the first of the two afore-mentioned ways was followed, helping us to understand the resilient character of the multiple-use management of tropical forests among the contemporary indigenous peoples of Mexico.

This analysis is possible thanks to the historical evidence recorded by two studies, one by Kelly and Palerm (1952) and the other by Ortiz-Espejel (1995), which were made in the Totonacapan territory, the region in which the indigenous village of Plan de Hidalgo is located. In order to alternate periods of agriculture (milpa) and forestry, traditional shifting agriculture uses long forest fallows between short periods of farming. The long fallow enables this traditional strategy to be sustainable, but it also requires of extensive areas of land. Under this scenario, each family in Plan de Hidalgo would require about $8-10$ ha of land. This figure is calculated as follows: we assume that each household plants a maximum of 2 ha of maize each year. We further assume that the same plot is planted for 3 successive years, at the end of which time it is given over to secondary forest and a new field cleared for maize. Assuming a fallow period of $10-12$ years, by the $10^{\text {th }}$ and $12^{\text {th }}$ years the secondary forest would have increased to 6 and 8 ha, respectively. There is evidence dating back to 1875 that supports the idea that, during the latter part of the $19^{\text {th }}$ and the first decades of the $20^{\text {th }}$ centuries, the households of Plan de Hidalgo and of the rest of the villages of the Totonacapan region based their material life on a shifting cultivation strategy (Kelly and Palerm 1952, Ortiz-Espejel 1995). During this period, indigenous families based their subsistence almost exclusively on products derived from the milpa (with perhaps some small tracts of sugar cane for home consumption) and from the secondary and mature forests. The sporadic commercial transactions came from several forest products, such as wild fruits (mainly zapotes and avocados), precious hardwoods (cedar and mahogany), chicle (sweet gum), and native rubber. It was not until the early 1940s that the first changes were brought about due to the boom in vanilla production that was prompted by the demands of the international market. This led to the use of secondary forests (fallow forests) as support and shelter for the climbing orchid, thus introducing a change in the conventional cycle of forest-milpa-forest that characterized shifting cultivation.

In contrast to other regions mentioned previously, the planting of vanilla was a late development in the Totonacapan region. In fact, although there are a number of $16^{\text {th }}$-century references to vanilla, which was used by the ancient Mexicans as a medicine and as a flavoring for chocolate, there is no indication that the Totonacapan region was an early source of this product (Kelly and Palerm 1952). It was introduced to the region perhaps as late as the late $18^{\text {th }}$ century. Half a century later, the expansion of vanilla was so important that, by 1950, Kelly and Palerm (1952:100) reported cultivation of this plant in three quarters of the households in Plan de Hidalgo (i.e., in 66 out of 89).

After the fall of the vanilla market in 1957-1958, which was caused both by an unusually strong frost in the region and by the onset of the commercialization of synthetic vanilla essence, numerous new cash crops began to be cultivated or gathered by the indigenous peasants of Plan de Hidalgo, including sugar cane, beans, tomatoes, sesame seeds, peppers, manioc, sweet potatoes, yams, and an assortment of wild fruits. Thus, during this period, new agricultural fields other than milpas were opened to cultivate species aimed at the markets, therefore introducing a new element to the entire strategy of management: the cash-crop fields.

During the early 1970s, "cattle fever" knocked on the doors of Plan de Hidalgo. This "fever" was stimulated by a general policy of rural development in the tropical lowlands of Mexico and Latin America, which was promoted by the international and national banks through credits, loans, and another mechanisms. With the rapid expansion of extensive cattle ranching through most of the coastlands along the Gulf of Mexico, significant deforestation took place in the Totonacapan region and throughout the tropical humid and sub-humid regions of Mexico, reducing the Mexican tropical rain forest to just $10-15 \%$ of its original distribution. However, the introduction of cattle and their pasturelands to the household economy 
in Plan de Hidalgo remained within the framework of the MUS, so that a certain amount of intensive livestock production was established. In fact, when contrasted to the conventional practice of livestock production in the tropics, the indigenous peasants of Plan de Hidalgo have adopted cattle ranching on a small scale (with potreros of 2.8 ha on average), where animals are fed a combination of grasses, legume trees, shrubs, and crop residues (leaves and other vegetative parts) from corn and sugar cane. Thus, the community of Plan de Hidalgo has adapted and integrated the practices of cattle ranching into the MUS.

The most recent external disturbance endured by the families of Plan de Hidalgo was the introduction of orange orchards in 1985 as a new economic option, initiated by the orange juice companies located in Mexico and in Florida, USA. During the early 1990s, a combination of low prices for beef, the resurgence of the vanilla market, and the opening of opportunities to commercialize unconventional wild products (such as the leaves of Chamaedorea spp. palms) gave rise to a new stage in the "survival game" played by the community. At the core of the indigenous village, the final outcome of this sequence of external economic events lasting almost one and a half centuries, was the maintenance of an increasingly more complex MUS among most households in Plan de Hidalgo. By 1990, $90 \%$ of the households based their subsistence on three or more productive units: nearly all of the households maintained milpas and home gardens; 73\% secondary forests; $64 \%$ potreros; $47 \%$ cash-crop fields; and $30 \%$ vanilla forests (Fig. 4).

This emerging new strategy, which represents a local adaptation of the ancient shifting cultivation strategy to the new challenges of the contemporary world (Fig. 7 ), is a management modality that is qualitatively superior to that previously practiced, because it results from an adaptation of the indigenous farmer to both ecological and economic constraints, which are, respectively, represented by environmental disturbances and eventualities and by market offers and risks. This novel MUS is not an "integral swidden cultivation" (Warner 1991) nor an "agro-forestry system," but a more advanced design that expresses the transition from an exclusively subsistence-oriented household economy, to a subsistence- and marketoriented production (see Toledo 1990).

Finally, it should be emphasized that not all indigenous communities, households, and peoples living in the humid tropics of Mexico practice this MUS, a fact that confirms the ample variation in the resilient capacity of each particular community. When explored in detail, every specific and particular case of indigenous management is the result of a struggle between two forces: 1) modernization, as represented by the agro-industrial model, which is based on the introduction of specialized, exclusively marketoriented, ecologically simplified systems, and 2) survival strategies of the indigenous peoples, which are based on modes, conceptions, and skills with cultural and historical roots (Toledo 1995, Alcorn and Toledo 1998).

The regional plans, the actions of development agencies, the political and technological changes, the enforced credits and, of course, the market forces, are a few of the main external factors that affect and shape the use of natural resources among indigenous communities. These factors threaten the permanence of the local communities and, whenever they become stronger than the community's own forces for resistance, they end up destroying them. Factors acting as resistant forces include: strong, but flexible, social organizations and institutions, various controls (such as tenurial rights and responsibilities), and strong cultural values.

\section{Permanence}

Ecosystem-oriented scientists doing research in the humid tropics have emphasized the importance of multiple-use management (Lugo 1995). For instance, Brown and Lugo (1990:26) conclude that: "Because natural forces will always tend to restore systems to their mature stage, the maintenance cost will increase with increased intensity of management. We believe that people benefit the most when all sectors of the model are active, e.g., when the landscape is most diverse and all systems are functional. Therefore, the management strategy should focus on finding out the optimal combinations of all four types of ecosystems (mature, logged, shifting cultivation and intensive agriculture)."

Paralleling the above, the MUS adopted by some indigenous groups in the tropical lowlands of Mexico resembles those prescribed by scientists, and is rooted in the practical world of daily life not in theoretical concepts. By maintaining landscape variety, indigenous peoples take advantage of the natural process of forest restoration, such that they derive benefits from the land conversion process itself, and 
from the various stages of land use, thus using available resources with maximal efficiency. Multiple use, compared with specialized use, signifies a lower production per land-use unit, but a higher production of the aggregate landscape.

Fig. 7. Transformation of the shifting cultivation system (shaded circles) to a multiple-use strategy (MUS) of management, as illustrated by the case of the Totonac community of Plan de Hidalgo, Veracruz. See text.

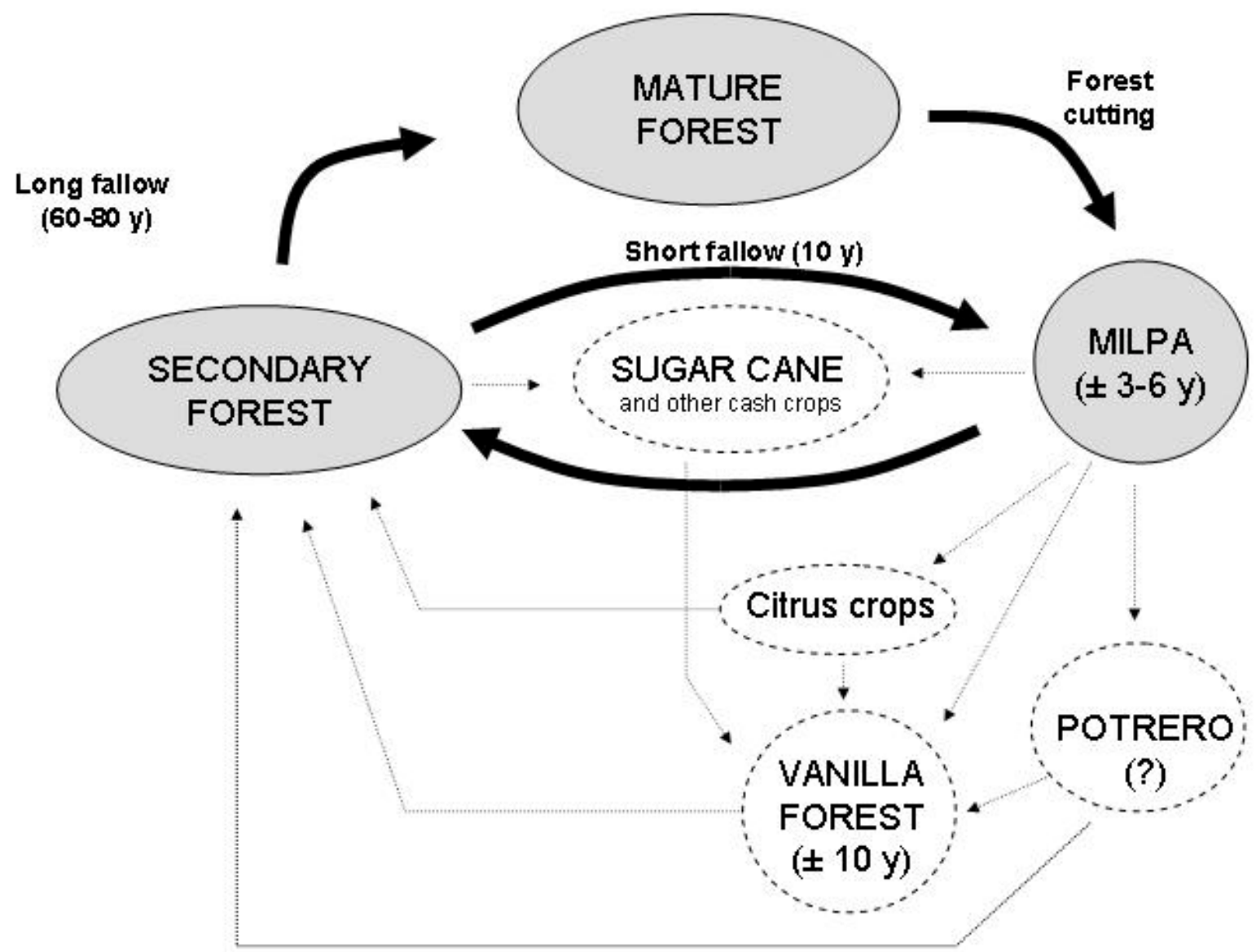

The above implies manipulation not only of species, soils, and masses of wild vegetation but, as was previously pointed out by Alcorn (1989b), of ecological processes. The idea of ecological succession is very clear in the minds of many indigenous producers (e.g., among the Chinantecs of Oaxaca, the Totonacs, and the Mayas) and can be empirically demonstrated not only by the existence of local terms to define this process, but by observations reported by several authors that indigenous farmers maintain the saplings of some useful species in their agricultural fields in anticipation of their role in forestry scenarios. For example, most of the species used as shade trees in the agro-forests of the indigenous coffee growers of Chiapas and Oaxaca are derived from their manipulation and care through the process of ecological succession (Bandeira et al. 2002; Bandeira personal communication). The sequential utilization of useful plant species in the various stages of the forest restoration process corroborates the practical significance of this local knowledge as a mode of adaptive management (Berkes et al. 2000).

Appropriately managed in terms of the economic opportunities and environmental constraints, this MUS tends to be enduring in the long term. In fact, although modern producers suppress the regenerative capacity of nature (ecological succession) through the 
implementation of (temporary) permanent, simplified, and very little diversified agricultural systems, indigenous peoples adopting a MUS make use of this regenerative capacity. Thus, paradoxically, while the modern permanent systems become increasingly more unstable as time passes, the MUS (although it tends to be perceived by the modern eye as unstable), if well managed, is in the long term dynamically permanent, because its treatment of uncertainty and unpredictability is intrinsic to tropical lowland ecosystems.

\section{CONCLUDING REMARKS}

The strategy analyzed in this paper when adopted by indigenous households and communities gives rise to a healthy socio-ecological system as theorized in the new "panarchy theory" (Holling 2001), because it is both creative and conserving and it combines learning with continuity. We propose that an appropriate design for an integrated farming system for the humid tropics can be derived from this indigenous experience, based on both the principles of the ecological resilience theory and on the philosophy of sustainability (Pandey 2002). Such a design should optimize production and use of natural resources, taking the indigenous strategy described here as its point of departure because it exemplifies a conservationist, resilient, permanent, social-ecological system. Furthermore, this MUS should be enhanced and perfected by modern science and technology through appropriate research, which should include not only the study of biological and ecological bottlenecks (cycles of plant and animal species, soil health, land-use dynamics) but also the social, economic, cultural, and even political factors that positively or negatively affect this management strategy.

In conclusion, as pointed out by some authors (Holling et al. 1998, Toledo 2001), contemporary scientists, academic institutions, and rural development agencies involved in the search for systems of sustainable management for natural resources in the humid tropics of the world must heed the lessons of indigenous, or local, social-ecological systems.

Responses to this article can be read online at: http://www.consecol.org/vol7/iss3/art9/responses/index.html

\section{Acknowledgments:}

The authors thank R. Dirzo, H. Goban, and D. PérezSalicrup for helpful discussions and insightful comments on an earlier draft of the paper. We especially thank Sergio Zárate, for his help with the translation and Pablo AlarcónCháires for his technical assistance. The manuscript was improved by comments from N. Barrera-Bassols and three anonymous reviewers. Finally, the paper was edited by Lorie Reeg. This paper, which synthesizes two decades of research, is dedicated to the indigenous peoples of the humid tropics of Mexico.

\section{LITERATURE CITED}

Alcorn, J. 1981. Huastec noncrop resource management: implications for prehistoric rain forest management. Human Ecology 9(4):395-403.

Alcorn, J. 1983. El Te'lom huasteco: presente, pasado y futuro de un sistema de silvicultura indígena. Biótica 8:315331.

Alcorn, J. 1984. Huastec Mayan ethnobotany. University of Texas Press. Austin, Texas, USA.

Alcorn, J. 1989a. An economic analysis of Huastec Mayan forest management. Pages 182-206 in J. O. Browder, editor. Fragile lands of Latin America: strategies for sustainable development. Westview Press, Boulder, Colorado, USA.

Alcorn, J. 1989b. Process as resource: the traditional agriculture ideology of Bora and Huastec resource management and its implications for research. Pages 63-77 in D. A. Posey and W. Balée, editors. Resource management in Amazonia: indigenous and folk strategies. New York Botanical Garden, New York, New York, USA.

Alcorn, J. 1990. Indigenous agroforestry systems in the Latin American Tropics. Pages 203-213 in M. Altieri and S. Hecht, editors. Agroecology and small farm development. CRC Press. Boca Raton, Florida, USA.

Alcorn, J., and V. M. Toledo. 1998. Resilient resource management in Mexico's forest ecosystems: the contribution of property rights. Pages 216-249 in F. Berkes and C. Folke, editors. Linking social and ecological systems. Cambridge University Press, Cambridge, UK.

Arellano, J. 1985. Estudios etnoecológicos en el sureste de México. Tesis de Biólogo, Facultad de Ciencias, Universidad Nacional Autónoma de México, Mexico City, Mexico.

Bandeira, F. P. de F., J. López-Blanco, and V. M. Toledo. 2002. Tzotzil Maya ethnoecology: landscape perception and management as a basis for coffee agroforest design. Journal of Ethnobiology 22:247-272. 
Berkes, F., J. Colding, and C. Folke. 2000. Rediscovery of traditional ecological knowledge as adaptive management. Ecological Applications 10:1251-1262.

Boege, E. 1988. Los Mazatecos ante la Nación. Contradicciones de la identidad étnica en el México actual . Ed. Siglo XXI.

Brown, S., and A. Lugo. 1990. Tropical secondary forests. Journal of Tropical Ecology 6:1-32.

Cabrera, A., C. Incháustegui, A. García, and V. M. Toledo. 2001. Etnoecología Mazateca: una aproximación al complejo kosmos-corpus-praxis. Etnoecológica 8:61-83.

Cook, G. F. 1921. Milpa agriculture: a primitive tropical system . Pages 307-326 in Annual Report of the Board of Regents of the Smithsonian Institution, Washington, D. C., USA.

Cortés, M. E. 1985. La Apropiación de los Recursos Naturales en Tres Comunidades Totonacas de la Costa, Veracruz, México. Publicación restringida. Dirección General de Culturas Populares/Secretaría de Educación Pública, México.

Cortés, M. E., and V. M. Toledo. 1991. La importancia de las estrategias indígenas en el trópico húmedo de México. Pages 423-480 in J. J. San José and J. Celecia, editors. Ecología Humana Aplicada a los Sistemas Agrícolas Tradicionales del Trópico Americano. Centro Internacional de Ecología Tropical, Caracas, Venezuela.

Davis, S. H., and A. Wali. 1994. Indigenous land tenure and tropical forest management in Latin America. Ambio 23:207-212.

De Ita, C. 1993. Nutritional requirement and human population growth in a tropical forest community in the south east of Mexico. Journal of Human Ecology 2:39-49.

De Ita, C. 1994. Playa del Tigre: estrategia nutricional en una comunidad zoque de la selva tabasqueña. América Indígena 54:299-340.

Denevan, W. M., J. M. Treacy, J. B. Alcorn, C. Padoch, J. Denslow, and S. Flores-Paitán. 1984. Indigenous agroforestry in the Peruvian Amazon: Bora Indian management of swidden fallows. Interciencia 9:346-357.

DeWalt, K. M. 1983. Nutritional strategies and agriculture changes in a Mexican community. University of Michigan, Ann Arbor, Michigan, USA.

Dufour, D. L. 1990. Use of tropical rainforests by native Amazonians. Bioscience 40:652-659.

FAO. 1957. Shifting cultivation. Unasylva 11:9-11.

Gómez-Pompa, A., and A. Kaus. 1990. Manejo tradicional de selvas tropicales en México. Pages 79-96 in A. Anderson, editor. Alternativas a la Deforestación. Editorial
Abya-Yala, Ecuador.

Gómez-Pompa, A., A. Kaus J. Jimenez-Osornio, D. Bainbridge, and V. M. Rorive. 1993. Mexico. Pages 483548 in National Research Council. Sustainable agriculture and the environment in the humid tropics. National Academy Press, Washington, D. C., USA.

Harrison, P. D., and B. L. Turner II, editors. 1978. Prehispanic Maya agriculture. University of New Mexico Press, Albuquerque, New Mexico, USA.

Holling, C. S. 1973. Resilience and stability of ecological systems. Annual Review of Ecology and Systematics 4:1-23.

Holling, C. S. 2001. Understanding the complexity of economic, ecological, and social systems. Ecosystems 4:390-405.

Holling, C. S., F. Berkes, and C. Folke. 1998. Science, sustainability and resource management. Pages 342-362 in F. Berkes and C. Folke, editors. Linking social and ecological systems. Cambridge University Press, Cambridge, UK.

Kelly, I., and A. Palerm. 1952. The Tajin Totonac. Part I. Smithsonian Institution. Institute of Social Anthropology, Publication No. 13.

Lucero S., and J. Avila. 1974. Las relaciones ecológicas en el Norte de la Chinantla. Cultura y Sociedad 2:48-58.

Lugo, A. 1995. Management of tropical biodiversity. Ecological Applications 5:956-961

Marten, G. G., editor. 1986. Traditional agriculture in southeast Asia: a human ecology perspective. Westview Press, Boulder, Colorado, USA.

Martin, G. J. 1993. Ecological classification among the Chinantec and Mixe of Oaxaca, Mexico. Etnoecológica 2:17-31.

Masera, O., M. J. Ordoñez, and R. Dirzo. 1997. Carbon emissions from Mexican forests: current situation and longterm scenarios. Climatic Change 35:265-295.

Medellín, S. 1988. Arboricultura y Silvicultura tradicional en una comunidad totonaca de la Costa. Tesis Maestría en Ciencias. Instituto Nacional de Investigaciones sobre Recursos Bióticos. Xalapa, Veracruz, México.

Mertz, O., and J. Magid. 2003. Shifting cultivation as conservation farming for humid tropical areas. [Online.] URL: http://www.geogr.ku.dk//projects/sluse/conference.

Moguel, P., and V. M. Toledo. 1999. Biodiversity conservation in traditional coffee systems of Mexico. Conservation Biology 13:11-21.

Nations, J. D., and R. B. Nigh. 1980. The evolutionary potential of Lacandon Maya sustained-yield tropical forest 
agriculture. Journal of Anthropological Research 36:1-30.

Nigh, R. B., and J. Nations. 1983. La agrisilvicultura tropical de los Lacandones de Chiapas. Pages 341-371 in Civilización: Configuraciones de la Diversidad. Centro Antropológico de Documentación de América Latina y CEESTEM (México) 1.

Noble, I. R., and R. Dirzo. 1997. Forests as humandominated ecosystems. Science 277:522-525.

Ortiz-Espejel, B. 1995. La Cultura Asediada: Espacio e Historia en el Trópico Veracruzano (el Caso del Totonacapan). Centro de Investigaciones en Antropología Social e Instituto de Ecología, A.C.

Ortiz-Espejel, B. 1999. Ganadería bovina, biodiversidad del suelo y sustentabilidad en el trópico veracruzano. Tesis de Doctorado Instituto de Ecología, A. C., Xalapa, Veracruz, México.

Pandey, D. N. 2002. Sustainability science for tropical forests. Conservation Ecology 6:r13. [Online.] URL: http://www.consecol.org/vol6/iss1/resp13.

Pierce-Colfer, C. J., and R. G. Dudley. 1993. Shifting cultivators of Indonesia: marauders or managers of the forests? FAO Community Forestry Case Study Series 6.

Pimentel, D., U. Stachow, D. A. Takacs, H. W. Brubaker, A. R. Dumas, J. J. Meaney, J. A. O’Neill, D. E. Onsi, and D. B. Corzilius. 1992. Conserving biological diversity in agricultural/forestry systems. Bioscience 42:354-362.

Posey, D. A., and W. Baleé, editors. 1989. Resource management in Amazonia: indigenous and folk strategies. Advances in Economic Botany 7:1-287.

Revel-Mouroz, J. 1972. Aprovechamiento y Colonización del Trópico Húmedo Mexicano. La vertiente del Golfo y del Caribe. Fondo de Cultura Económica. México.

Roosevelt, A. 1989. Resource management in Amazonia before the Conquest: beyond ethnographic projection. Pages 30-62 in D. A. Posey and W. Baleé, editors. Resource management in Amazonia: indigenous and folk strategies. Advances in economic botany 7.

Thrupp, L. A., S. B. Hecht, and J. O. Browder. 1997. The diversity and dynamics of shifting cultivation: myths, realities and policy implications. World Resources Institute, Washington, D. C., USA.

Toledo, V. M. 1990. The ecological rationality of peasant production. Pages 51-58 in M. Altieri and S. Hecht, editors. Agroecology and small-farm development. CRC Press, Boca Raton, Florida, USA.

Toledo, V. M. 1992. What is ethnoecology?: origins, scope and implications of a rising discipline. Etnoecológica 1:521.
Toledo, V. M. 1995. Peasantry, agro-industriality, sustainibility: the ecological and historical grounds of rural development. Interamerican Council on Sustainable Agriculture. Working Papers 3:1-27.

Toledo, V. M. 2001. Biodiversity and indigenous peoples. Pages 330-340 in S. A. Levin, editor. Encyclopedia of Biodiversity. Academic Press, San Diego, California, USA.

Toledo, V. M. 2002. Ethnoecology: a conceptual framework for the study of indigenous knowledge of nature. Pages 511-522 in J. R. Stepp, F. S. Wyndham, and R. K. Zarger, editors. Ethnobiology and Biocultural Diversity. International Society of Ethnobiology.

Toledo, V. M., and C. Carrillo, editors. 1992. Conservación y Desarrollo Sostenido en La Selva Lacandona: el caso de Las Cañadas, Chiapas. Centro de Investigación sobre Energía y Desarrollo, A.C., México.

Toledo, V. M., B. Ortiz-Espejel, and S. MedellínMorales. 1994. Biodiversity islands in a sea of pasturelands: indigenous management in the humid tropics of Mexico. Etnoecológica 3:37-50.

Toledo, V. M., A. Batis, R. Becerra, E. Martínez, and C. H. Ramos. 1995. La selva útil: etnobotánica cuantitativa de los grupos indígenas del trópico húmedo de México. Interciencia 20:177-187.

Tudela, F., editor. 1989. La Modernización Forzada en el Trópico: El caso de Tabasco. El Colegio de México, Mexico City, Mexico.

Vásquez-Dávila, M. A. 2001. Etnoecología Chontal de Tabasco, México. Etnoecológica 8:42-60.

Warner, K. 1991. Shifting cultivators: local technical knowledge and natural resource management in the humid tropics. FAO. Community Forestry Notes 8.

Watters, R. F. 1971. Shifting cultivation in Latin America. FAO. 